\title{
STYLE PANORAMA OF UKRAINIANBUTTON ACCORDION MUSIC OF THE END OF THE XX - THE BEGINNING OF THE XXI CENTURIES INTRODUCTION
}

\section{Stashevskyi A. Ya.}

\section{INTRODUCTION}

Modern button accordion music, which has a wide range of different genres and forms of music (created, including by Ukrainian composers), clearly shows a unique complex of artistic and expressive means, capable of accurately and convincingly embodies the highly artistic tasks of composer and performer creative work that in its turn justly confirms the high positions and the great potential of this kind of music instrumental art in the focus of the artistic processes today. This complex of means also determines the peculiar stylistic face of modern button accordion language, in which, on the one hand - typical instrumental-timbre specificity, on the other - a wide range of style archetypes and features of the academic music-instrumental tradition is clearly manifested.

Coverage of the stylistic features of individual artworks in modern button accordion music (or all creative work of certain composers) and their characteristics were systematically or occasionally engaged by various scholars (in particular V. Bychkov, D. Kuzhelev, A. Honcharov, Ya. Oleksiv, O. Pokazanyk, A. Stashevskyi and others). However, these issues remain relevant today, due to the constant emergence of new compositions created in different stylistic directions, and the need for further and thorough development of other aspects and issues related to the style of modern button accordion music. The most important task of modern musicology in the sphere of accordion and button accordion art is the question of a holistic study of the whole style panorama of Ukrainian button accordion music, first of all, created in the last decades of the $\mathrm{XX}$ and the beginning of the XXI centuries; characterization, identification and systematization of its stylistic directions and varieties.

Therefore, the purpose of this article is to illuminate the style panorama of button accordion creative work of contemporary Ukrainian 
composers through consideration of the stylistic features of the most famous works. The tasks that are subordinated to the stated purpose are: characterization of the figurative sphere of individual button accordion works, analysis of their genre-style features and the identification of the main stylistic directions of modern Ukrainian music for button accordion in outlined time.

\section{Vector "neo-" (neo-folklore, neo-baroque, neo-classic, neo-romanticism)}

One of the bright representatives of neo-folklore in Ukrainian music is Anatolii Haidenko, a composer whose bulk of creative work belongs to this direction. During the last decades of the past and the beginning of the new centuries, the author has created a whole set of small and large works, based on the music and linguistic foundations of folklore of different peoples, including Ukrainian, Russian, Georgian, Croatian, Bulgarian, Serbian, Hungarian, Moldovan, Romanian etc.

The most significant achievement in the composer's button accordion creative work is works of large cyclical forms, which are also based on the intonation complex of music folklore. Three-part Sonata No. 1 vividly transforms the various typical components of Western Ukrainian folklore: the image of improvisational instrumental music, the use of instrumental and rhythm-organizational features, the onomatopoeia of folk sounds (trembits, bells, etc.), and the use of peculiar people's ensemble attribute. However, the sonata has a rather dynamic and powerful dramatic development, intense intonation transformations, and organic formation.

Sonata No. 2 Ancestral Echoes and Concert No. 2 From Ancestral Times recreate archaic layers of Ukrainian folklore, including the music traditions of ceremonial and calendar holidays. At the same time, these works used an updated composer complex of expressive means and instrumental techniques. The first part of the concert - On the Night of Kupala depicts a picture of the ancient action of the times of pagan RusUkraine: the entertainment of young people on the Kupala holiday by the river with jumps through the campfire. The second part - Kupala's round dances - depicts the lyric-romantic sensual side of popular action. It enhances the sonorous function of music presentation (the purl of water, the flickering of crickets, etc.). The final part - Kupala entertainments - 
the apogee of folk festivities, a kaleidoscope of wild dances and fun games.

One of the most interesting Ukrainian composers - masters of the "new folk wave" not only in the button accordion music, but also in other genres, including orchestral genres, - Volodymyr Zubytskyi - created a number of large cyclical opus for button accordion in the style of neofolklore, they are "the golden fund" of the world original button accordion repertoire. These are works such as Suite No. 2 Carpathian (1975), Sonata No. 2 Slavic (1987), Bulgarian Notebook (1987) and others.

A four-part Suite No. 2 Carpathian is justly regarded as a milestone on the path of the evolution of national button accordion music. The author gives up the names of the parts of the cycle (which is not typical for the suite genre). This important factor, along with the peculiarities of formbuilding and the principles of dramaturgy, allows us to interpret the work from the standpoint of genre synthesis between the suite and the sonatasymphonic cycle. Suite music reflects a striking author's origin of stylization of Carpathian music folklore in the traditions of the academic genre. Therefore, through the modern language of the work folk music basis is clearly felt, which manifests itself in the specifics of intonation organization, the involvement of other expressive means, typical for "neofolklore" style, such as color harmony, metro-rhythmic, textures, timbre and sonorous juxtapositions, imitation of ethno-sounding and onomatopoeia.

The people's-genre basis of this work is based on the stylization of contrasting (slow and dancing) folk tunes - dumas, kolomyikas, hutsulkas, etc., which build a figurative plot from lyrical-epic reflections to unbridled dance, full of joy and celebration. In this work, which, by author's definition, is a suite, in addition to the clear influence of sonata-symphonic architectonics, we also observe features such as frescoes, mosaics of the unfolding of the material, which give the suite characteristic features of the rhapsody genre.

Sonata No. 2 Slavic consists of six parts performed by attacca, and the ratio of the parts in the cycle is based on the figurative and paced contrast, which plays the basic principle of sonata. After all, the form of Slavic is open and more inclined to the suite norms with the through development of dramaturgy. 
The main theme of the sonata is based on the intonations of ancient Slavic (Ukrainian, Bulgarian, Serbo-Croatian) melodies. Music language of the work, which fully reflects the stylistic features of neo-folklore, at the same time, reveals a wide range of means that combine traditional approaches and the latest techniques, first of all, sonorism, aleatoric techniques, minimalistic layers, combination of non-rhythmic with rhythmically organized structures.

The Bulgarian Notebook is an eight-part cycle of suite plan with vivid programmability of the parts. The language vocabulary of the work harmoniously combines the music components of Bulgarian and Hutsul folklore. Unlike the Carpathian Suite and, in particular, the Slavic Sonata, this cycle of the author is devoid of powerful intensive development. On the other hand, such dramatic "simplicity" enhances the perception and significance of the folklore-ethnographic intonation component. A considerable number of different and limited in size parts are a single "kaleidoscope" of conflict-free alternation of moods, often changing each other without stopping (attacca).

The neo-folklore features are also characteristic of some works of the composer Anatolii Biloshytskyi, in particular his Suite No. 3 Spanish, in which the author, under the influence of F. G. Lorca's poetry performs a vivid stylization of the Spanish folk tradition. Using a set of expressive factors, characteristic for the folk music of Spain (intonation-motive, metro-rhythmic, harmonic), the composer convincingly creates a true Spanish color, produces “... an image of national character, Spanish national spirit, which is emphasized by the leisurely pace of tempo-rhythm in the image of a proud male and, vice versa, emotional-dynamic contrast, impulsive temperament in creating of female image" 1 .

The epic line as a component of folklore research of modern button accordion creative work is successfully developed in the nine-part cycle of Andrii Stashevskyi Suite-notebook Ancient Kyiv Frescoes (2005), in which the author refers to the images of "ancient" of the historical times of Kyiv Rus. According to the researcher D. Kuzheliev, the work "...consists of nine colorful paintings of the historical past, "written out" with illustrative

${ }^{1}$ Фенюк П. Хрестоматія баяніста. Ч. 4. Українська сучасна оригінальна музика. Київ : НМАУ ім. П. І. Чайковського, 2008. С. 22. 
truth of epic images. In the multi-colored palette suites bright genre sketches stand out - Bylyna, Round dances, Instrumental Tunes, as well as landscape paintings - Gloomy dawn, In groves and oak trees, Nabat. Bells of St. Sophia, Entertainments of buffoons. The graphic and associative effect of the sound images provides the bright, characteristic theme of the suite. It relies on a sophisticated palette of colorful soundtracks in the spirit of traditional pictorial and epic illustrations" $"$.

One of the most illustrative works in modern button accordion neofolklore is the opus of Volodymyr Runchak Suite No. 2 Ukrainian (1980; 1987; 2003), which represents the organic synthesis of ethno-intonation elements with a wide range of modern means of music composition. The cycle presents three diverse parts: Recitative - a dramatic composition of the rhapsody type with an improvisational and declamatory presentation of the melody; Toccata - impulsive-rhythmic with dynamically-effective motility at the basis of dramaturgy; Vesnianka is something like a genre picture, the theme of which reproduces intonations of quasi-folklore and only resembles the manner of the Carpathian folk melodies.

Orientation of Ukrainian composers to neo-baroque traditions in modern music for button accordion is a frequent occurrence and is proving to be a stable and long-lasting trend. Yurii Shamo is one of the striking representatives of the modern music of the button accordion genre, for whose creative work neo-baroque is an important and characteristic feature. The author pursued his neo-baroque aspirations in a series of opus cycles. Partita Piccolo is a four-part cycle, where Part I is "icy cold" Chorale; Part II - agitated-anxious and at the same time restrained Fugue; Part III - Recitative, color-harmonized, contemplative-meditative; Part IV - impulsive Toccata. In addition to the genre attribute of the baroque, which manifests itself in the author's choice of genre models for the components of the cycle, the music of Partita-piccolo is inspired by polyphonic techniques and principles of dramatic formation.

Valentyn Bibik's sonata for button accordion, which also embodies the genre features of the polyphonic cycle with the fugue, is a two-part structure where, unlike tradition (that is, the prelude is the fugue), the first C. 264.

${ }^{2}$ Кужелев Д. О. Баянна творчість українських композиторів. Львів : Сполом, 2011. 
part of the sonata is a fugue and the second is a postlude. Both pieces are written at a restrained pace: Sostenuto and Moderato. Asceticism and laconic use of expressive means are the main features of the composition in this work. This is evident in the application of the predominantly modal method of material unfolding and in the overall constructiveness of the dramaturgy, which is based on the gradual saturation of the texture. As a typical example of a chamber sonata, this work by Bibik appeals to the socalled intellectual music, which, unlike the majority of button accordion sonatas saturated with emotion and extroverted openness, demonstrates in its musical movement the sphere of meditative concentration, inner immersion.

The bright sonata cycles of Ukrainian composers, which are a synthesis of sonata and polyphonic forms, include Volodymyr Balyk's Sonata on $D S C H$. Using the intonation-style and symbolic elements of D. Shostakovych's music creative work, first of all the DSCH monogram, a quotation from fragment II of the 15th symphony of the master and other stylistic factors, the composer has created a beautifully stylized workdedication to the great artist. The sonata consists of three parts - Ostinato, Recitative, and Fugue and contains rather intensive polyphonic methods of form-structure construction, material development, texture organization, etc.

An interesting page of national button accordion literature is Suite No. 1 Portraits of Composers (1979-88) by Volodymyr Runchak, which is a striking example of music stylization of certain author's styles of different epochs and their reinterpretation from the point of view of the modern composer. V. Runchak chose style models by J.S. Bach, D. Shostakovych, N. Paganini, and I. Stravinsky. Parts of the cycle were written with quite a significant break in time, so each of them also received the status of an independent work. In this regard, the concept of suite as a single cycle reveals a certain convention, but on the other hand, as a unifying idea of this work, separate landmark linguistic and stylistic attributes appear, which are inherent in the creative personality of each of the selected geniuses and settled in the music culture on the level of the "intonation fund of the era" (Asafiev's term) ${ }^{3}$.

3 Сташевський А. Володимир Рунчак «Музика про життя...» Аналітичні есе баянної творчості. Луцьк, 2004. - 199 с. 
Part I of the cycle is Bahiana. BACH Meditations, the basis of which is the intonation monograph by J. Bach - BACH, and the work's dramaturgy is based on the stylization of the late Baroque polyphonic method of composition; part II - D. Shostakovych inheritance, with its intense percussion movement, reminiscent of the style of the composer's quartet; part III - At the Portrait of N. Paganini, in the intonation-stylistic limits of modern button accordion language, reproduces the virtuosoromantic manner of the instrumental expression that is characteristic of the great violinist. Allusions and indirect quotations of certain fragments from N. Paganini's works are clearly felt in this work of art: La campanella, Eternal Movement, etc.; part IV - Dedicated to I. Stravinsky - vividly represents the neo-folkloristic face of the last of the chosen geniuses, imitating certain textural, linguistic and intonation elements of his Petrushka and Rite of spring.

Continuing the genre line of music portraits-stylizations, which completes the "neo"-directions of the style of contemporary button accordion music, the composer Volodymyr Zubytskyi has created several such dedications, including the play In dedication of Johann Strauss (1988), the suite Portraits of composers (1988) for the button accordion orchestra, as well as the Concert for button accordion with the chamber orchestra Rossiniana (1992).

Rossiniana is a one-piece work without much innovation in form (sonata form is used). From a stylistic point of view, this neo-romantic virtuoso concert is a striking example of the literal stylization-imitation in button accordion music. The work is written in a collage style with extensive use of quoting material by musician Gioachino Rossini, in particular the Figaro Recitative from the opera The Barber of Seville and others.

In the aspect of neo-romanticism, the creative work of Anatolii Biloshytskyi appears who is rightly called "the last romantic" in contemporary domestic literature for button accordion. The creative work of the composer continues the traditions of Ukrainian button accordion romanticism of the 1950s - 1970s, laid by V. Dykusarov, K. Miaskov and other composers, but at a new level of decoration.

Large cyclical forms, which also contain the sonata features of dramaturgy, in the button accordion creative work of the composer first 
and second concert partitas are distinguished; whose linguistic features reproduce neo-romantic imagery. Concert Partita No. 1 is a four-part cycle where Part I is Prelude, Part II is Peripezie, Part III is Improvisazione, Part IV is Finale. The partita composition is built on the principle of alternating slow and moving parts.

Concert Partita No. 2 (K., 1990) is even more marked by romantic breath, which is also clearly reflected in the genre definition of its parts: And part I - Intrada. Elegy, II - Intermezzo, III - Ostinato, IV - Recitative and Eternal Movement. The music of both partitas by A. Biloshytskyi is romantic and encouraged by spirit. Indeed, it is characterized by bright imagery, touching sentiment and multicolored feelings, melodism, expressive thematism, expressiveness of the horizontal-intonation movement. But along with the romantic features, these works of the author also contain a rather fresh impression of modern music language, which brings them closer to the artistic traditions of post-romanticism. A certain tension of harmony, its colorism, sometimes with dissonant coloring, enriched chord, diverse rhythm of motive structures, and freer mode-tone organization of form composition are among these features.

The neo-baroque, neoclassical and neo-romantic directions make up not the massive by the number of works, but a powerful layer of contemporary button accordion repertoire in artistic and aesthetic sense. The originality of the complex of the chosen expressive means, the diverse palette of compositional decisions and findings allowed the composers to clearly embody the conceptual foundations of artistic and stylistic models of the past in a new meaningful change.

\section{Jazz-academic synthesis}

The stylistic updating of the music language of modern button accordion music could not avoid the influence of such a rich and vibrant direction of the music culture, which is jazz. Volodymyr Zubytskyi was the first domestic composer in the button accordion genre. He was able to bring and creatively use the elements of jazz music language in composing works of classical and academic direction. He created a large five-part cycle Partita concertanta No. 1 in modo di jazz improvizasione (1979), that it, partita No. 1 in the traditions of jazz improvisation. Despite its name and its wide appeal to jazz, such as mode-intonation, harmonics, 
metro rhythms and other specific features, this work is still a model of academic or so-called serious music.

Jazz-specific elements of the music language of the partita, which appear to be quite impressive and bright, are used by the composer quite carefully, even concisely. Some parts, such as Aria and Epilog, are generally devoid of jazz music culture, and only a harmonious consonance unites them with other parts of the composition. The other structural sections of the partita are saturated with linguistic and jazz semantics much more clearly. In particular, syncopation as the main rhythm attribute of jazz creates the desired grotesque and ironic colur of the figurative side of the second part of the cycle (Toccatta-burletta).

The author's concept of jazz-academic synthesis is slightly different in Partita concertanta No. 2 in modo di jazz improvizasione (1990). Like the previous work, Concert Partita No. 2 also belongs to the type of concert or symphonic partita, but unlike it, it consists of only three parts and has more chamber dramaturgy. The jazz specificity of the second partita's music language is much larger and brighter. In addition to the basic linguistic components (melody, harmony, rhythm), jazz features is also manifested in the more inventive manner of texturing the material, as well as in the "sound imitation" of the jazz orchestra and its individual instrumental solos; percussion instrument imitations, vocal-jazz intonation, etc. Three parts of the partita are devoid of any genre or program names and are identified only by the initial tempo characteristic remarks: Allegro energico, molto ritmato; Andante tranquilo; Presto energico.

In his jazz-partitas V. Zubytskyi, engaging intonation and linguistic components of jazz art, creates the academic-concert compositions, in which the principle of "concert" is concentrated in such factors as scale of the form, instrumental virtuosity, saturation and diversity texture, orchestration, dynamics of dramaturgy, overall efficiency and vivid imagery. Taking the key principles of the instrumental partita genre as a basis, the composer puts into it the updated artistic content, carefully keeping the traditions of classical formation.

One of the striking examples of engaging elements of jazz features in contemporary button accordion literature is the cyclic work of composer Anatolii Biloshytskyi Partita concertanta No. 3 quazi tradizione jazzimprovizasione (Concert Partita No. 3 in the traditions of jazz 
improvisations, 1988). Unlike the previous two partitas of the author, the Third Jazz Partita is characterized by a chamber of dramaturgy, and all five different parts of the cycle, connected by continuity of performance (attacca), sound in one breath.

The play Capriccio in modo jazz (1991) by Andrii Stashevskyi also reflects the jazz-academic direction of the button accordion repertoire. The work vividly represents the virtuoso, specifically button accordion textural and technical possibilities with the use of stylistic features inherent in modern jazz art. V. Vlasov classifies the work as an example of jazz rock style in the button accordion music ${ }^{4}$, but it also contains stylistic manifestations of late bi-bop, hard-bop and fusion.

Borys Myronchuk's cyclical compositions, the basis of an expressive complex of which involves a wide range and algorithms of modern pop and jazz broadcasting, are slightly different from a number of major concert works written by Ukrainian composers in recent decades. These are compositions such as Sonata (1996) and Jazz-rock Partita (2002). If the author's button accordion sonata has a distant but visible form of the sonata's contours, then his partita emits a rather blurred structural outline. With the powerful intensity of dramatic development, it tends to fusionimprovisation music based on declared intonation-thematic blocks that to some extent distracts this work from academic norms of music form organization. On the other hand, B. Myronchuk's works (especially the last one) bring a significant stylistic update to the music-linguistic concept of the "vocabulary" of modern button accordion music.

\section{From modern to avant-garde}

Modernist manifestations as a regular process of updating the music language in the process of development of domestic button accordion music began to emerge in the period of complete "subordination" of the artistic and aesthetic paradigm of button accordion art to the ideas of romanticism, that is, as early as in the 1970s. Even in the creative work of traditional composers, there were occasional novelty sprouts that brought freshness and novelty of music expression to their style aura.

\footnotetext{
${ }^{4}$ Власов В. Школа джаза на баяне и аккордеоне. Одесса : Астропринт, 2008. С. 76.
} 
Composition Concert diptych by Yurii Shamo - is a work in which each of the parts has its own composed structure and is made of various (slow and motor) episodes. The common identity and intonation closeness are united parts of the diptych. The melody of the slow sections is distinguished by the remoteness of the tonal tendencies, the generous use of the chromatic sounds, the moves at wide intervals, and the dissonance of the vertical in the polyphonic combinations. Moving episodes reveal a rhythm-intonation firmness that creates a combative, sometimes aggressive character. However, the work is distinguished by a fairly transparent texture, the absence of its excessive load.

The composer Volodymyr Runchak has made a significant contribution to the development of modern button accordion literature, enriching it with a number of great works, among which the Sonata No. 1 Passione (1985-89). This work, along with some other cycles, reflects one of the main thematic directions of the composer's creative work - the spiritual human search. Therefore, it is no coincidence that the work was given exactly the name that defines its ideological content. The work is one-part and combines the principles of the expansion of music material, which are peculiar to polyphonic forms and, in fact, to sonata symphonic and concert music. This is manifested in the powerful pressures and downturns of music waves, in the constant changing of different texture types, in the transformational conversions of the basic intonation ideas of the work.

A striking example of button accordion modernism is another work by V. Runchak - the seven-part Messe da Requiem (1982). The music language of the work combines the modernist manifestations of the organization of the intonation-thematic side with different elements, means and techniques of the avant-garde. This is especially true for the involvement of polystylistics and extra-music artistic and informational levels of the text (verbal formation - citing of M. de Unamuno's poetry).

Volodymyr Zubytskyi's two-part Sonata No. 1 (1978) has marked the beginning of the development of the modern Ukrainian button accordion sonata, and at the same time confirmed the presence and perspective of the strong creative potential of its author, who was at the beginning of his creative career at that time. 
In this work, the composer chooses a rather innovative approach to the problem of form organization of the composition: a two-part cycle built on the principle of tempo and thematic-image contrast, where a fugue exposes instead of the traditional sonata allegro of the first part and the second part is approximated to the form of a four-part cycle. Sonata combines polyphonic principles of music texture formation with homophonic harmonic. V. Zubytskyi's compositions, in which modern means of expression are dominated, include such cycles as Sonata No. 2 Slavic (1987), Sonata No. 3 Fatum for the trio (2000), Mourning Music (1978), Six Meditations by C. Baudelaire for button accordion and flute (1988), Concert Partita No. 1 (1979), Lacrimoso for two button accordions and flute (1989), Misterioso for two button accordions, flute and cello (1989) and others.

Victor Vlasov's Suite-Symphony $(1977 ; 2005)$ is one of the first works in Ukrainian button accordion music that openly and fully implements the modernist complex of intonation-expressive potential. The composition consists of three parts that have no names (Andante maestoso, Allegro molto; Anndante; Presto) and recreate a three-phase art conceptual form-model with active opening and final parts and a slow middle. The first and the third parts are characterized by intensive development, symphonic approaches to the deployment of intonation-thematic material and general forms of movement. The middle part is a slow, philosophical and contemplative with a slight tinge of lyrics.

The music language of the work emits "elastic" dissonance, chordharmonic color, and many sonorous-noise effects. It very creatively develops original specific-button accordion play methods and the means (various clusters and glissando, percussion-effects on the instrument body, bellows, register switches, different types of vibrato and more). In addition, in the work the author quite inventively uses the specific features of the structure of the sounds of both keyboards in terms of ease of playing and development of original texture-elements and formulas.

Suite Five Views on the GULAG Country (1991) in the field of modernization of music expression of modern button accordion creative work successfully continues the artistic research of the composer and represents a new for button accordion literature branch of the figurativelythemed tree, which (according to A. Semeshko), can be defined as a socio90 
political, social ${ }^{5}$. The five colorful sketches of the suite vividly depict scenes from the life of political prisoners in the distant Siberian camp. Colorful programmability of the cycle is promoted not only by the names of the parts (Zone, Walking Stage, Blatni (Criminals), Tree felling, Pakhan and stooge), but also invented by the author the means of music instrumental sound.

A concert triptych on the theme of the painting by Hieronymus Bosch The Last Judgment (1992) leads to the semantics of biblical writing, including the composer's attempt to create a music version of an apocalyptic story of a painting by a prominent Dutch Renaissance artist. The music language of the work, including the original button accordion complex of means in three parts of the triptych, reproduces the characteristic features of three different artistic and stylistic concepts of music art. So, "... the first part - the Paradise - reveals a visible connection with impressionism. A demanding melody, spice of harmonies, instability of moods, refinement, and elegance - all this paints a picture of a carefree paradise. The second part - Temptation - contains the features of the Baroque style, which for the first time in the history of music has fully demonstrated its capabilities of a deep and versatile embodiment of the world of human emotional experiences. The music of the third part - the Hell - reminds us of the inevitability of punishment. Here, the composer uses cutting-edge avant-garde music means (sonorous sound, extra-music complexes, clusters), which gives the music a hellish, destructive character",6.

Suite No. 1 Images (1991) by A. Stashevskyi is a small three-part cycle, whose dramaturgy is based on the contrasts of its parts. Performed in neo-impressionist perspective, these parts-sketches re-open the button accordion's sound capabilities by embodying fresh timbre syntheses, colorful harmonic consonance, various sonorous effects, and more. "The

${ }^{5}$ Семешко А. Анотація. В. Власов. П'ять поглядів на країну ГУЛАГ. Панорама сучасного репертуару для баяна (акордеона). Вип. 1. Тернопіль : Богдан, 2004. С. 2.

6 Семешко А. Анотація. В. Власов. Концертний триптих на тему картини Ієроніма Босха «Страшний суд». Тернопіль : Богдан, 2003. С. 29. 
striking attraction of this music to "impressionism" particularly illuminates its colorful fairy-tale imagery" ${ }^{\prime 7}$.

The interest in modern composing technologies and principles of music composition has been expressed by Viktor Vlasov - a composer who during his long creative activity has created a large number of opuses in different styles of button accordion music. In avant-garde art, one should also refer to his play Infinito (Infinity) (1994), which is written in two versions - for button accordion solo and for button accordion with chamber orchestra. The structure of this postmodern work consists of 15 autonomous sound blocks that are interconnected. The originality of the compositional decision of the author is manifested in the "granting of the right" to form an algorithm of alternation of performing these blocks to the artist himself, thus depriving the parameter of the form of this music work from the traditionally stable level into the sphere of mobile-variable expressive means.

The play Telephone conversation (man and woman) (1997) is written by the author in the genre of performance art, which holds the music text of the work in a certain theatricalizing. The role of conditional "theatrical characters" by the author's idea is performed, on the one hand, by the button accordion party (woman), on the other - by the performer (man) himself, using verbal means (lines according to the text). The music language of the composition is based on the rough melodies of polyphonic and interval-chord character with the varied rhythm, but at the same time, the music is expressed intonationally. Its figurative-emotional semantics reaches a wide psychological range - from "pleading requests" to "threats" and "outright hysteria". In addition, the play is generously saturated with a variety of sonorous-noise effects that carry a specific phonetic function imitation of the phone call ringing, deep "human breathing" by the valve of the shutter, accelerated "heartbeat" by beats on the open bellow, "hanging up" with a loud click of the register switch etc.

Composition In the Centaurus constellation (2003) is an embodiment within the instrumental button accordion timbre of the themes of the Space, the Universe, the problem of correlation between the macro- and the micro

${ }^{7}$ Василенко А. І. Андрій Сташевський. М. А. Давидов. Історія виконавства на народних інструментах (Українська академічна школа). Луцьк. : ВАТ «ВОД», 2010. C. 267. 
world, the categories of time and space. The music language of the work is rich in color and sound, but the aleatory techniques and timbre-sonorous play an important role in the development of the play's composition. An interesting find of semantic manifestation is the "twisting" of the stave at the end of the work into a closed circle with "endless" sonic movement in it, which symbolizes the curvature of space in the universe.

Volodymyr Runchak's creative work in the postmodernism is represented by a series of button accordion works, among which there is a large (about twenty minutes of sounding) four-part cycle of Quasi-Sonata No. 2 Music about life - an attempt of introspection (2001). The complexity of his music language is manifested in the author's use of a set of modern compositional techniques and methods of writing, in particular the minimalist principles of organizing sound matter in the form of pointilistic-rehearsal technique (separate fragments).

Symphony for button accordion, symphony orchestra, reader, rock band, and video sequence Passions for Vladyslav (1982, 1988; also for button accordion with piano) is one of the most interesting monumental works in the modern button accordion music. The uniqueness of the work lies in its considerable artistic content and in the experimental essence of many decisions of the genre-style concept, which the author has successfully implemented in this composition.

A two-part large-scale work consisting of Epitaph and Passacaglia (views on M. Ge's painting What is the truth?) is dedicated to the composer-founder of modern button accordion music Vladyslav Zolotarov, who passed away at the age of 33. In addition to music quotes from V. Zolotarov's button accordion works, the symphony has also used the literary texts of the composer's epistolary heritage (fragments of his letter to Edison Denysov), which allowed V. Runchak to convey in his work all the intricacies of the inner spiritual world of the artist who lived a difficult life and suffered from misunderstanding.

The originality and novelty of the compositional idea of the symphony in the stylistic content is manifested in the use of the latest multimedia technologies by the author (involving a slide projector with a slide demonstration of M. Ge's painting What is the truth?, video clip, etc.), rock band instruments (synthesizer, electric guitar, bass guitar, percussion) 
and in the use of the verbal text layer (reader party, recitation of canonical texts by orchestrators, etc.) and a number of polystylistic layers.

A striking representative of the avant-garde direction, especially in the button accordion music, is Oleksandr Shchetynskyi, one of the leaders of composers of the "new generation" in Ukrainian contemporary music. In the 1980s, the author created such opuses as the Sonata (1993), The Sad Song (1994), and the cycle Four Intentions (1995) for button accordion. These works were first performed by Moscow button accordion player Joseph Puritz.

At the beginning of 1990s, the composer wrote another solo button accordion work for this artist - Poco misterioso, marked by a vivid pointillist character. The following compositions by O. Shchetynskyi in the 1990s are represented by the chamber and ensemble direction, in particular the play Two...in parallel...do not intersect? for button accordion and clarinet, composition Together for violin and button accordion, as well as the sextet Quiet Voices for clarinet, button accordion and string instruments.

Odessa composer Carmela Tsepkolenko has dedicated a series of works for button accordion, most of which have been written for various chamber and instrumental compositions. The One Who Comes Out of the circle (1993) is the first solo composition for the author's button accordion. The Duel for violin and button accordion (1995) and Peoples are broken by fatigue, the cemetery play for button accordion and percussion (2000), represent the button accordion in a duet with other instruments. The following works of the composer demonstrate her attraction to the unconventional compositions of chamber and instrumental ensembles, where the button accordion plays not the least function: If the thread breaks, she won't be able to collect all the pearls again for saxophone, percussion, button accordion and bass (1998); Exit - cantata for soprano, clarinet, piano and button accordion (1996).

The button accordion creative work of another Odessa composer Liudmyla Samodaieva, who very successfully uses this instrument in various chamber compositions, is interesting and original. She has written: Suite (1994) and Three sincerities (1995) for button accordion and violin; Quasi Sonata for button accordion (1995); Velymer-style Rondo for violin reader and button accordion reader (1996); Don't Touch Me (by 
T. Arsenieva's poem) for voice and button accordion (1998); Quasi-quintet for 2 violins, alt cello and button accordion; Metamorphoses-2 for button accordion and string orchestra (1999); Pas-de-Trois for saxophone, button accordion and piano (1999); Formulas for clarinet and button accordion; performance My Hohol for button accordion, violin and percussion (2003).

The button accordion creative work of Yuliia Homelska, also a representative of the Odessa Composition School, was presented by the program work for violin and button accordion Behind the shadow of sound (2000). It is fair to note that the vast majority of chamber and instrumental opus with the button accordion involvement was created by Odessa composers at the request of the famous button accordion artist and propagandist of contemporary music Ivan Yerhiev.

The play Intrigues by Serhii Pyliutykov for button accordion and saxophone is a virtuosic, one-part work which is extensively used the latest achievements of the 20th century music language and is based on serial methods of working with music texture. The figurative content of the composition radiates dramatic features in some places, and the principle of soloist competition connects its dramaturgy with genre traditions of "concerto".

\section{CONCLUSIONS}

The stylistic system of modern button accordion music is a set of basic stilettos of the present academic music tradition, which are actively cultivated in other chamber-instrumental branches and developed both individually (i.e. internally, autonomously), and in the close intersection and interplay of their own artistic and technological canons with the similar ones.

Despite the stylistic versatility and pretentiousness that is characteristic of the broad community of domestic button accordion music of the academic tradition, it is easy to distinguish in it the main trunk vectors, whose linguistic and stylistic foundations are based on a set of those or other established features, mostly of one stylistic field, era, direction, individual author.

Thus, the basis of the stylistic system of modern button accordion music consists of several fundamental vectors, in particular: neo-folklorethe creation of modern compositions of large and small forms with a clear 
theme reliance on folk origins; reproduction of stylistics and "spirit" of folk music in the expanded instrumental genres; neo-baroque, neoclassicism, neo-romanticism - realization of artistic concepts of the past or their foundations in the conditions of a new (modern) music-linguistic paradigm; modern - a contemporary statement based on an expanded linguistic-intonation complex and with the preservation of traditional norms of theme and tone-function; avant-garde (postmodern) - use of the latest compositional technologies, innovative ideological and aesthetic artistic concepts, etc; jazz-academic direction - actual synthesis of language-style systems of traditional and modern jazz and genres, forms and methods of dramaturgy of academic music culture.

It should be considered that a significant number of modern button accordion compositions are created at the intersection of these style directions. They contain the characteristics of two or more styles and patterns and represent the so-called phenomenon of stylistic synthesis in modern music.

\section{SUMMARY}

This article is devoted to the general overview and characterization of style palette of button accordion creative work of modern Ukrainian composers. The description of individual button accordion works is given, through the analysis of their genre-style features and ideological-figurative content. The basic fundamental vectors of the stylistic system of the modern button accordion music of the Ukrainian composers, which are presented in several directions, are revealed. Neo-folklore - the creation of contemporary compositions of large and small forms with a clear reliance on the theme of folklore origins, reproduction of stylistics and "spirit" of folk music in the expanded instrumental genres. Neo-baroque, neoclassicism and neo-romanticism - the realization of artistic concepts of the past or their foundations in the context of the modern (new) music and linguistic paradigm. Modern - a contemporary statement based on an expanded linguistic-intonation complex and with the preservation of traditional norms of theme and tone-function. Avant-garde - use of the latest compositional technologies, innovative ideological and aesthetic artistic concepts, etc. Jazz-academic direction - actual synthesis of language-style systems of traditional and modern jazz and genres, forms 
and methods of dramaturgy of academic music culture. It is stated that the style system of modern button accordion music represents a spectrum of the basic stiletotypes of the academic music tradition of the present, which function in other chamber-instrumental branches of music art and develop both autonomously and in close intersection and mutual influence of their own artistic and technological canons with the similar ones.

\section{REFERENCES}

1. Василенко А. I. Андрій Сташевський. М. А. Давидов. Історія виконавства на народних інструментах (Украӥнська академічна школа). Луцьк. : ВАТ «ВОД», 2010. С. 266-267.

2. Власов В. Школа джаза на баяне и аккордеоне. Одесса : Астропринт, 2008. 160 с.

3. Кужелев Д. О. Баянна творчість українських композиторів. Львів : Сполом, 2011. 208 с.

4. Семешко А. Анотація. В. Власов. П'ять поглядів на краӥну ГУЛАГ. Панорама сучасного репертуару для баяна (акордеона). Bun. 1. Тернопіль : Богдан, 2004. 28 с.

5. Семешко А. Анотація. В. Власов. Концертний триптих на тему картини Ієроніма Босха «Страшний суд». Тернопіль : Богдан, 2003. $31 \mathrm{c}$.

6. Сташевський А. Володимир Рунчак «Музика про життя...» Аналітичні есе баянної творчості. Луцьк, 2004. - 199 с.

7. Фенюк П. Хрестоматія баяніста. Ч.4. Українська сучасна оригінальна музика. Київ : НМАУ ім. П. І. Чайковського, 2008. 160 с.

\section{Information about the author: \\ Stashevskyi A. Ya. \\ Doctor of Art Criticism, Professor,}

Head of the Folk Instruments Department,

Kharkiv State Academy of Culture 4, Bursatskyi uzviz, Kharkiv, 61057, Ukraine 